Transatlantic Port Issues.

Author(s): Mary R. Brooks and Larissa M. van der Lugt

Source: Journal of the Transportation Research Forum, Vol. 49, No. 3 (Fall 2010),

pp. 133-154

Published by: Transportation Research Forum

Stable URL: http://www.trforum.org/journal

The Transportation Research Forum, founded in 1958, is an independent, nonprofit organization of transportation professionals who conduct, use, and benefit from research. Its purpose is to provide an impartial meeting ground for carriers, shippers, government officials, consultants, university researchers, suppliers, and others seeking exchange of information and ideas related to both passenger and freight transportation. More information on the Transportation Research Forum can be found on the Web at www.trforum.org. 


\title{
Transatlantic Port Issues
}

\author{
by Mary R. Brooks and Larissa M. van der Lugt
}

This paper examines differences between Northwest Europe and Eastern North America with respect to port commercial activities, port policy, port hinterland access and competition, port governance, and port security. While the volume of traffic on the transatlantic trade route has grown, its share of world trade with Europe has declined slightly. The authors explore the relevant contextual issues the ports on the trade route have experienced in the last decade, and using the Baltazar and Brooks (2001) Environment-Strategy-Structure framework, examine the structure and strategies followed by ports as they seek to deal with the changing environment (context) on all routes, not just the transatlantic.

\section{INTRODUCTION}

The port industry has undergone significant change in the last 25 years in large measure due to two significant revolutionary changes in global trade and transportation. The first of these was the widespread implementation of containerization. The year 2006 marked 50 years since Malcolm McLean first shipped "boxes" (really truck chassis) on the Ideal-X from New Jersey to Houston and irrevocably changed the way most manufactured goods are transported (Levinson 2006). Containerization was a key enabler of the wave of globalization that has occurred over the last quarter century. The need for terminal investment to support this wave meant many ports, desirous of participating in the burgeoning traffic growth that containerization promised, searched for ways to finance and build such investment. The second revolution was in the governance and management of ports. In the 1980s and 1990s, governments, around the world faced with increasingly unmanageable budgetary deficits, were seeking ways to reduce deficits and provide port services more efficiently while, concurrently, encouraging ports to be self-sufficient if not generators of revenue for government. The era of new public management and port reform began (discussed in Brooks and Cullinane 2007). The restructuring of port activities often included a move towards privatization or corporatization of ports, but most frequently led to a growth in the use of concessions to achieve these objectives. The most common concessions were for container terminal activities. The confluence of these two profoundly changed the cargo movement business and the role that ports play in this business, with traditional servicing of tanker and dry bulk activities remaining a core business activity.

This paper is about the port industry servicing the North Atlantic trade route. We use the generic Environment-Strategy-Structure configuration, as expanded by Baltazar and Brooks (2007), as a framework for its descriptive analysis of the port industry on both sides of the North Atlantic trade route. Core to this concept is that the performance of ports is related to the fit between environment (context) and, the structure and strategy of the port. While this paper will not focus on the output measure of performance, relating the context to the structure and strategy of ports provides the ability to explore the differences between ports on the U.S. East Coast of North America and those in Northwest Europe.

Using Eurostat data, the paper begins by examining the trade that underpins port demand on the transatlantic and how that trade is evolving; where possible, given data limitations, it examines the ports that service that trade. The focus then turns to the specific sector of port activity most influenced by the globalization activities of the last 25 years - containerization. Here, it is clear that the transatlantic trade is not the key trade route in global trade development, but that other factors influence the prospects for key Atlantic ports, and these will be discussed. As is the case for ports 
globally, port hinterland accessibility influenced by port congestion and security have become the critical context issues for ports in the region, so the next section will examine these issues more closely and what the Atlantic ports are doing to address them. As the ability of port authorities to respond to globalization, competitive pressures, and congestion is a product of the governance of the port, the following section focuses on the changing role of the state in port governance first in Europe and then in North America, leading to a discussion of current port governance, a structural issue. Finally, the paper will close with an examination of port management strategies in response to these structure and context changes. Throughout the paper, the authors explore the developments in the specific regional contextual issues the ports on the trade route have experienced in the last decade and examine the differences in management structures and resultant port management strategies between both sides of the Transatlantic maritime trade.

\section{THE EVOLUTION OF TRANSATLANTIC TRADE}

The transatlantic trade (defined as Eureopean Union-United States and Canada) ${ }^{1}$ is the smallest of the major global container trades in manufactured goods. While initially much more dominant, as one of three global trade lanes in the early 1990s, it has lost its position as the Asian trades have grown to dominate. In the early 1990s, trade on three routes - the transatlantic, the transpacific, and the Asia-Europe - accounted for $50 \%$ of global container trade. With the rise of Asia, the transatlantic share of global container traffic fell to less than 5\% by 2007 (Drewry Shipping Consultants 2008).

Europe-North America has long been one of the major trade lanes in the world's movement of goods. Total seaborne external trade of the 27 members of the European Union (EU-27) with North America accounts for about $6 \%$ of the total seaborne external trade of the EU (Table 1). While the absolute volume of traffic has grown over the period from 1999 to 2008 by $15.0 \%$, North America's share of EU-27 trade with the world has declined as the EU-27's trade with Asia has grown, particularly in the 2000-2006 period.

Table 1: Europe - Canada/U.S. Trade Development 1999-2008 (Seaborne Trade in 000 Tons)

\begin{tabular}{l|c|c|c|c|c|c|c}
\hline & \multicolumn{3}{|c|}{ EU-27 with } & \multicolumn{3}{c|}{ EU-27 with the World } & $\begin{array}{c}\text { U.S. Canada } \\
\text { Share }\end{array}$ \\
\hline Year & Import & Export & Total & Import & Export & Total & \% \\
\hline $\mathbf{1 9 9 9}$ & 86,670 & 77,464 & 164,135 & $1,865,300$ & 572,069 & $2,437,368$ & $6.73 \%$ \\
\hline $\mathbf{2 0 0 0}$ & 90,918 & 90,954 & 181,872 & $2,001,493$ & 613,417 & $2,614,910$ & $6.96 \%$ \\
\hline $\mathbf{2 0 0 1}$ & 85,636 & 86,546 & 172,182 & $2,061,248$ & 569,370 & $2,630,618$ & $6.55 \%$ \\
\hline $\mathbf{2 0 0 2}$ & 77,507 & 91,847 & 169,354 & $2,062,969$ & 610,481 & $2,673,450$ & $6.33 \%$ \\
\hline $\mathbf{2 0 0 3}$ & 79,539 & 90,508 & 170,046 & $2,174,356$ & 642,697 & $2,817,053$ & $6.04 \%$ \\
\hline $\mathbf{2 0 0 4}$ & 81,500 & 96,405 & 177,905 & $2,340,770$ & 670,171 & $3,010,941$ & $5.91 \%$ \\
\hline $\mathbf{2 0 0 5}$ & 79,234 & 98,382 & 177,616 & $2,407,780$ & 718,723 & $3,126,503$ & $5.68 \%$ \\
\hline $\mathbf{2 0 0 6}$ & 81,346 & 91,581 & 172,927 & $2,468,422$ & 728,593 & $3,197,015$ & $5.41 \%$ \\
\hline $\mathbf{2 0 0 7}$ & 89,512 & 85,632 & 175,144 & $2,551,411$ & 746,568 & $3,297,979$ & $5.31 \%$ \\
\hline $\mathbf{2 0 0 8}$ & 107,654 & 81,093 & 188,747 & $2,529,735$ & 789,239 & $3,318,974$ & $5.69 \%$ \\
\hline
\end{tabular}

Source: Eurostat (2009)

The figures in Table 1 do not show the decline in port traffic due to the global economic crises. Before September 2008, port volumes were softening and after that date, a significant and substantial decline in port traffic occurred; in 2009, most major ports in the region reported doubledigit declines in traffic. As of January 2010, port volume levels have not recovered to their 2007 highs, although some recovery has occurred in some ports. The full impact of the global economic crisis on future port traffic is not yet clear. 
Including Mexico and decomposing Europe's trade with Canada, Mexico, and the United States (Figure 1), the most stable have been the smaller volume of European exports to Canada and the trade with Mexico, while European exports to the United States have declined significantly. Since the recession of 2001-02, European imports from North America have risen, and most notably from the United States. Mexico's participation in trade with the E.U. has been smaller than Canada's but EU exports to Mexico have been rising in recent years and were similar to Canada's in 2008. Mexico's participation in transatlantic trade has been mostly through transshipment on the U.S. east coast or in the Caribbean.

In terms of trade in manufactured goods and component parts, the Europe-North America maritime container trade is still substantial in Europe's total maritime trade. However, the share has declined over the last two decades as the rise of China has altered global trading patterns, especially in the container trades. In the container trades, the transatlantic trade is the smallest of the four main trades, with a diminishing share over time as it is the slowest growing of the four; the fastest growing is Asia-Europe (13.0\% 2006 over 2005) followed by transpacific (10.5\%), intra-Asian trade (9.7\%), and then transatlantic at 4.1\% (Watson 2007). Comparing 2007 traffic over 2006, there was a retrenchment in both transpacific and intra-Asia trades, perhaps reflecting the softening of market conditions over 2007, while the Asia-Europe and transatlantic continued to grow, albeit at less than 5\% (Drewry Shipping Consultants 2008). The transatlantic container trade, slow-growing and stable, reflects a mature trade route between developed countries.

For both the European and the North-American seaports, the transatlantic trade is a substantial one, although not dominating their traffic. Based on the individual statistics as published by the ports through their Web sites, it can be concluded that, for the Northwest European ports, the intra-European trades have the largest share. In most cases, the Asian trades follow. Antwerp and Bremerhaven are ports where the transatlantic trade dominates with about a $15 \%$ share, according to data available from individual ports' Web sites. On the North American side of the Atlantic Ocean, the traffic pattern is less clear. While consolidated calendar year 2007 data is available by port

Figure 1: North America's Trade with the EU by Sea in Tons 2000-2008

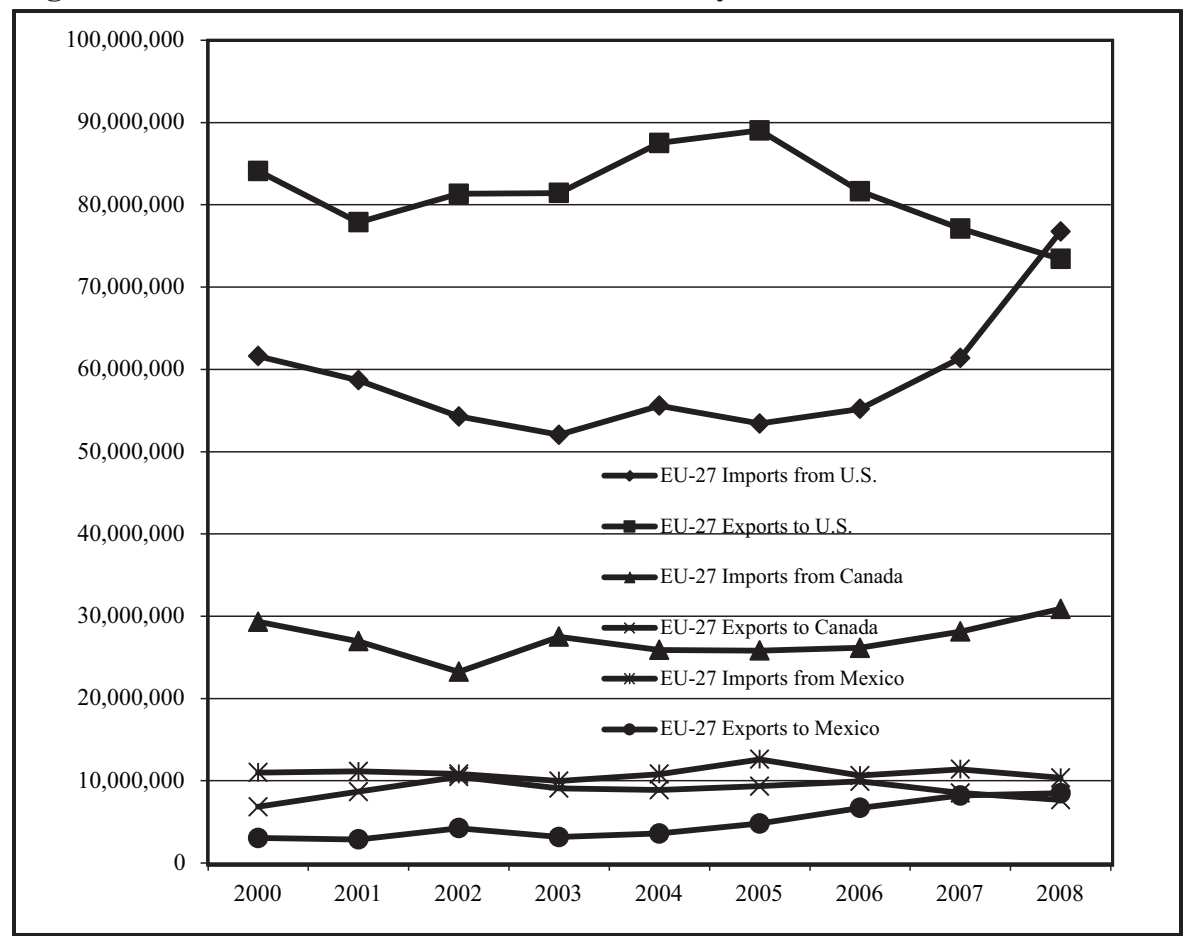

Source: Eurostat (2009) 
(foreign and domestic) from the Data Navigation Center of the U.S. Army Corps of Engineers, the 2006 data are more detailed. However, that detail is by commodity (U.S. Army Corps of Engineers 2008), and does not distinguish whether the foreign origin or destination is Europe, Canada, or Asia. Therefore, the role of transatlantic trade for U.S. East Coast ports cannot be determined from existing public data sources. Likewise, the Canadian statistics available do not afford the opportunity to examine waterborne trade (as has been done using Eurostat statistics).

\section{Trade Developments Within Europe}

Western European markets continue to mature. The total market volume in Europe's most important countries and in traditional market sectors, such as consumer goods and automotive products, are showing moderate growth rates, contrasting with the booming growth in these markets in the 1970s and 1980s. The largest segment in Europe's maritime trade is liquid bulk. In the European Union, there are around 116 refineries, many of them located in seaports (Notteboom 2009). The Port of Rotterdam has the largest share in the transshipment of liquid bulk with a throughput of 194 million tons in 2007 (Port of Rotterdam Web site). Other large liquid bulk ports are Marseille (France), Bergen Ports (Norway), Le Havre (France), and Wilhelmshafen (Germany), followed by ports in Italy (Trieste, Augusta) and UK (Tees \& Hartlepool, Milford Haven and Southampton) (ITMMA 2009). The liquid bulk trades are highly imbalanced with large import flows and relatively small export flows. The second largest segment is dry bulk, mainly consisting of iron ore and coal. These products are inputs for steel plants and electricity generating stations and are therefore highly captive to particular ports. The five most important ports are Rotterdam (Netherlands), Hamburg (Germany), Dunkerque (France), Amsterdam (Netherlands), and Antwerp (Belgium), followed by ports in the UK (Immingham), Spain (Gijon), and Italy (Taranto) (ITMMA 2009). Just like liquid bulk, dry bulk shows a significant imbalance with large import volumes and smaller export ones. Although containerized trades have a minor share in terms of volume, their impact on port systems is substantial in terms of growth rates and infrastructure demands. While demand in Western Europe might have matured, changing production and supply chain patterns have induced strong growth in container flows in and out of Europe. Globalization, outsourcing of production to low cost countries, and postponement in manufacturing and assembly have led to increasing containerized flows both intra-Europe and between Europe and other continents. In some ports, this meant that growth rates above $10 \%$ were achieved between 2004 and 2008 .

The developing countries in Central and Eastern Europe have shown substantial economic growth over the last decade. The center of gravity for economic trade, therefore, is shifting from west to east, and likely to result in different trade patterns in the future. It is already clear that the northern German and Baltic ports already have benefitted from this shift.

\section{Trade Developments in North America}

The shipment of energy is the largest single trade handled at U.S. ports, with Philadelphia, New York, Portland, Baltimore, and Boston hosting 92.3\% of tanker calls in the North Atlantic region of the United States in 2007, and the first two of these hosting $76.5 \%$ of the tanker calls. In the South Atlantic port range, five ports handled $72.4 \%$ of the tanker calls in 2007, but the business was more evenly spread (U.S. Maritime Administration 2009b). For Atlantic Canada, energy (including coking coal) was the largest single import and export, accounting for $92.0 \%$ of imports and $65.2 \%$ of exports for the four Atlantic Canadian provinces in 2005 (Brooks et al. 2009). In 2006, Port Hawkesbury in the Strait of Canso, Saint John, and Quebec City were the primary export ports for energy on the Canadian East Coast, while energy imports were serviced at a slightly wider range of ports, including Come-By-Chance and Sydney (Statistics Canada 2009). 
The recent downturn in trade in dry bulk has affected ports on the North Atlantic. It is too soon to know the impact in terms of port statistics, but a significant volume of traffic at Canadian ports remains commodities. The largest destination (49.1\%) for the Canadian overseas outbound volume in 2006 was Asia followed by Europe (28.5\%). Total inbound shipments from overseas ports declined 5.2\% in 2006, with energy shipments (of crude petroleum) from ports in both Europe and Africa, accounting for the majority of the decline. Of the tonnage arriving at Canadian ports from overseas, the largest share originated in Europe (30.7\%) (Statistics Canada 2009: 15). Using another data source, it is perhaps interesting to note that for the $9.5 \%$ of 2007 Canadian traffic by value bound for West Europe and East Europe, air provides significant competition to the marine mode (Table 2) at the top end of the product value range. However, marine is the primary mode from a volume perspective.

Table 2: Canada's Exports by Origin, Destination and Mode, 2007 (C\$000)

\begin{tabular}{lcccl}
\hline $\begin{array}{l}\text { Total Exports } \\
\text { Country of Destination }\end{array}$ & $\begin{array}{c}\text { Eastern } \\
\text { Provinces }\end{array}$ & $\begin{array}{c}\text { Western } \\
\text { Provinces }\end{array}$ & $\begin{array}{c}\text { Total } \\
\mathbf{2 0 0 7}\end{array}$ & $\begin{array}{c}\text { Main Modes Used } \\
\text { (\%o of total value) }\end{array}$ \\
\hline United States & 244,748 & 109,461 & 354,210 & Road (49), Rail (20) \\
Other Countries & 56,521 & 37,834 & 94,355 & Marine (64), Air (27) \\
West Europe & 30,536 & 8,514 & 39,050 & Marine (58), Air (38) \\
Asia & 10,569 & 20,676 & 31,245 & Marine (83), Air (15) \\
Latin America & 7,466 & 4,121 & 11,587 & Marine (44), Road (23) \\
Middle East & 3,023 & 1,778 & 4,800 & Marine (63), Air (27) \\
East Europe & 2,004 & 847 & 2,851 & Marine (51), Air (34) \\
Oceania & 1,437 & 771 & 2,208 & Marine (50), Air (36) \\
Africa & 1,457 & 1,120 & 2,578 & Marine (59), Air (23) \\
Other & 30 & 6 & 36 & Marine (66), Air (32) \\
\hline Total & $\mathbf{2 9 3 , 2 6 3}$ & $\mathbf{1 4 5 , 6 6 7}$ & $\mathbf{4 3 8 , 9 3 1}$ & \\
\hline Sourc: Tran & & & \\
\hline
\end{tabular}

Source: Transport Canada (2009), Table EC-12.

\section{Development of Container Port Systems}

The rising tide of container shipments over the past 25 years has been one of the most dominant trends noted at both European and North American ports. By 2007, three North European ports were in the top 15 of global container ports while no East Coast U.S. or Canadian ports could make that claim. The top 50 container ports included six North European ports - Rotterdam (ranked 6), Hamburg (9), Antwerp (14), Bremen-Bremerhaven (22), Felixstowe (30), and Le Havre (39) — but only two U.S. East Coast ports-New York New Jersey (19) and the consolidated ports of Georgia (41). Virginia had been ranked $48^{\text {th }}$ in 2004 but disappeared from the 2007 rankings (Journal of Commerce 2008). 
Table 3: Top 20 Container Lines and Service Patterns (2009 rank)

\begin{tabular}{lll}
\hline Rank (1) & Company & Major Ports Called (2) \\
\hline 1 & A P Moller-Maersk & A, B, F, G, LH, M, NY, R, V \\
2 & Mediterranean Shipping Co. (MSC) & A, F, G, LH, M, NY, R, V \\
3 & CMA-CGM Group & A, B, F, G, LH, M, NY, R, V \\
4 & Evergreen Group & A, B, F, G, LH, NY, R, V \\
5 & APL & A, B, F, G, LH, M, NY, R, V \\
6 & Cosco Container Lines & A, B, F, G, LH, NY, R, V \\
7 & Hapag-Lloyd Containerline & A, G, H, LH, M, NY, R, V \\
8 & China Shipping Container Lines & A, F, G, H, LH, NY, R, V \\
9 & NYK & A, B, G, H, LH, M, NY, R, V \\
10 & Hanjin & A, F, G, LH, NY, R, V \\
11 & OOCL & A, B, G, H, LH, M, NY, R, V \\
12 & MOL & A, F, G, NY, R, V \\
13 & Hamburg Sud Group & A, B, F, G, LH, NY, R, V \\
14 & K Line & A, B, F, G, H, LH, NY, R, V \\
15 & Yang Ming & A, B, F, G, NY, R, V \\
16 & CSAV Group & A, F, G, NY, R, V \\
17 & Hyundai Merchant Marine (HMM) & A, B, F, G, LH, NY, R, V \\
18 & Zim & A, F, G, H, LH, NY, R, V \\
19 & Pacific International Lines (PIL) & A, R \\
20 & United Arab Shipping & A, B, F, G, LH, NY, R, V \\
\hline
\end{tabular}

Notes: 1. Rank is based on TEUs of deployed shipboard capacity at the end of June 2009 as cited by AXS-Alphaliner. (http://www.axs-alphaliner.com/top100/index.php).

2. Port key: $\mathrm{A}=$ Antwerp, $\mathrm{B}=$ Bremen Ports, $\mathrm{F}=$ Felixstowe, $\mathrm{G}=$ Georgia Ports, $\mathrm{H}=$ Port of Halifax, $\mathrm{LH}=$ Le Havre, $\mathrm{M}=$ Port of Montreal, NY=NewYork New Jersey, $\mathrm{R}=$ Rotterdam, $\mathrm{V}=$ Virginia Ports. It was difficult to confirm Hamburg information and so Hamburg has not been included.

Source: Created by the authors based on information supplied by the port Web sites or port directories and any not listed on port Web sites were cross-referenced to the shipping line Web sites.

Most of the major global liner shipping companies (in the top 20) provide marine container services to the United States and to Europe, but not all provide services to Canada directly (Table 3). That said, most are concerned with servicing the Asian trade to the key ports and have Europe-Asia and transpacific services. The transatlantic service may be an extension of Asia-Europe services or part of a Suez service that calls only Mediterranean ports. As not all lines or ports provide detailed routing information, a more definitive conclusion is not possible.

\section{Northwest European Container Port System}

About 130 seaports in Europe handle containers; of these, 40 accommodate intercontinental container services (Notteboom 2009). The Northwest European container port range consists of both relatively large load center ports and a substantial number of regional ports. In the Mediterranean, a few purely transshipment ports exist, whereas pure transshipment ports are absent in Northwest 
Europe. The emergence of the transshipment ports in the Mediterranean began in the latter half of the 1990s with Gioia Tauro, Malta, Algeciras, and Port Said growing strongly as the hub and spoke philosophy was adopted following the Asian ports' lead. Such growth was also certainly related to the rapidly increasing container flows between Asia and Europe. The already existing deepwater load center ports in Belgium, the Netherlands, and Germany, fulfilling the transshipment function, can explain the absence of new transshipment ports in Northwest Europe. Table 4 lists the 15 major ports in Europe with their throughput volumes and growth. Growth has been phenomenal at all Northwest European ports except Felixstowe, which struggled with its infrastructure investment plans during the period.

One of the characteristics of the ports in Northwest Europe is that they are located in relative proximity and, therefore, Europeans think of continental access in terms of gateway regions rather then individual ports (Notteboom 2009). Figure 2 shows Europe's multi-port gateway regions and how they are connected to their hinterlands. The contestable hinterlands of the Northwest European ports are substantial. Rotterdam, Antwerp, Hamburg, and, to a lesser extent, Bremen all have overlapping hinterlands in the central part of Europe, particularly Germany, Austria, and Switzerland. In Northeast Europe, ports like Hamburg and Bremen have benefitted from economic growth in central and eastern Europe, and become bigger ports as a result. Ports in the Baltic, like Saint Petersburg, Tallin, and Klaipeda, have shown steady growth figures over the last decade.

Table 4: Top 15 European Container Ports in 2008 and Growth Since 1995

\begin{tabular}{|c|c|c|c|c|}
\hline $\begin{array}{l}\text { Rank } \\
2008\end{array}$ & European ports & $\begin{array}{c}1995 \\
(000 \text { TEU) } \\
\end{array}$ & $\begin{array}{c}2008 \\
(000 \text { TEU) } \\
\end{array}$ & $\begin{array}{c}\text { Growth } \\
1995 \text { - } 2008\end{array}$ \\
\hline 1 & Rotterdam & 4,787 & 10,784 & $125.3 \%$ \\
\hline 2 & Hamburg & 2,890 & 9,737 & $236.9 \%$ \\
\hline 3 & Antwerp & 2,329 & 8,664 & $272.0 \%$ \\
\hline 4 & Bremen & 1,518 & 5,448 & $258.9 \%$ \\
\hline 5 & Valencia & 672 & 3,597 & $435.3 \%$ \\
\hline 6 & Gioia Tauro (transshipment port) & 1,155 & 3,468 & $200.3 \%$ \\
\hline 7 & Algeciras (transshipment port) & 970 & 3,324 & $242.7 \%$ \\
\hline 8 & Felixstowe & 1,924 & 3,200 & $66.3 \%$ \\
\hline 9 & Barcelona & 683 & 2,569 & $276.1 \%$ \\
\hline 10 & Le Havre & 689 & 2,500 & $262.8 \%$ \\
\hline 11 & Marsaxlokk (transshipment port) & 528 & 2,337 & $342.6 \%$ \\
\hline 12 & Zeebrugge & 515 & 2,210 & $329.1 \%$ \\
\hline 13 & Genoa & 965 & 1,767 & $83.1 \%$ \\
\hline 14 & Southampton & 600 & 1,710 & $185.0 \%$ \\
\hline \multirow[t]{6}{*}{15} & Piraeus & 615 & 431 & $-29.9 \%$ \\
\hline & Total top 15 & 20,840 & 61,746 & $196.3 \%$ \\
\hline & Total Europe & 33,280 & 90,710 & $172.6 \%$ \\
\hline & Share Rotterdam & $14 \%$ & $12 \%$ & $-14.3 \%$ \\
\hline & Share top 3 & $30 \%$ & $32 \%$ & $6.7 \%$ \\
\hline & Share top 15 & $63 \%$ & $69 \%$ & $9.5 \%$ \\
\hline
\end{tabular}

Note: The bolded and italicized ports are those located in Northwest Europe.

Source: Notteboom (2009). 


\section{The U.S. East Coast Port System}

With the development of containerization by Malcolm McLean out of New Jersey, the Port of New York New Jersey had an early start in the race to dominate container port development in North America. Other ports on the eastern seaboard of North America were not far behind with new facilities being developed along the seaboard in the 1960s. With the development of stack train technology by American President Lines for rail service out of Los Angeles and Long Beach in 1984, the trade patterns shifted with a large volume of U.S. consumer demand being serviced via land bridge, that is goods transported out of Asia and over the U.S. West Coast ports and onward by rail to U.S. Midwest and East Coast markets.

Figure 2: Europe's Multi-port Gateway Regions

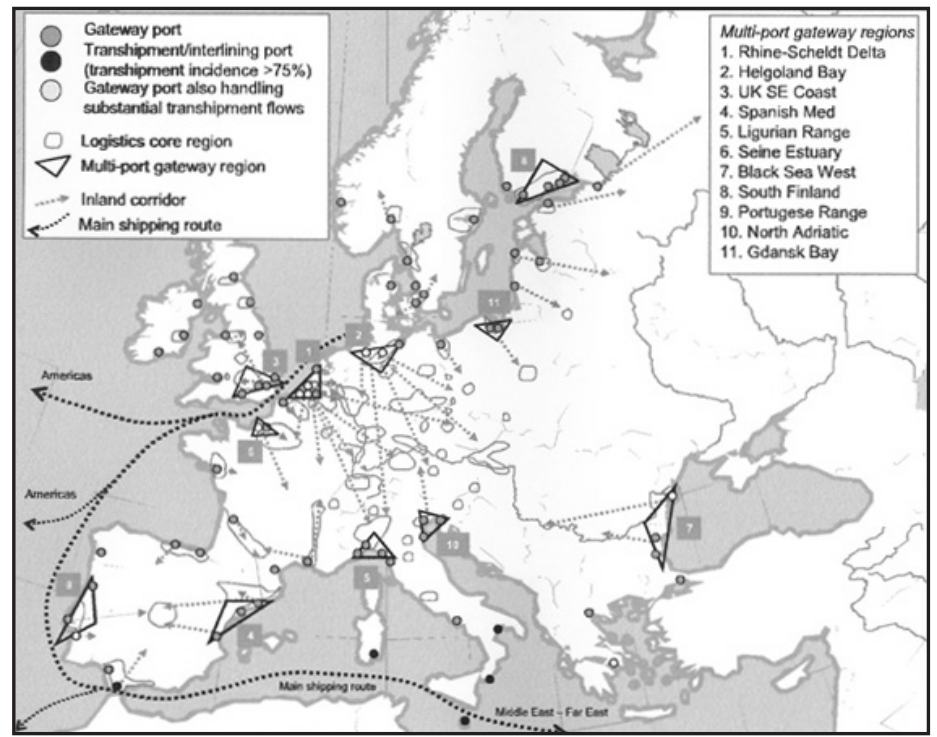

Source: Notteboom (2009)

In more recent years, the Panama Canal has become a means of accessing the eastern markets with all-water routes from Asia through the Panama Canal to Gulf and East Coast ports to more local truck-accessible destinations. By 1997, 20 U.S. container ports handled almost all of the U.S. container traffic (more than 95\%), with 10 container ports on the U.S. East Coast handling about two-fifths of the total (Table 5). Growth over the last 12 years has been particularly strong, driven by consumer demand fueled by relatively easy credit, but there has been little change to the east-west coast split in terms of share of traffic, and four ports-New York New Jersey, Savannah, Norfolk, and Philadelphia - all acquired more than a doubling of volumes. The pattern of growth in container terminal throughput in the United States is on a scale similar to that of Europe. 
Table 5: Top U.S. East Coast Container Ports in 2008 and Growth Since 1997

\begin{tabular}{rlrrr}
\hline $\begin{array}{l}\text { Rank } \\
\mathbf{2 0 0 8}\end{array}$ & U.S. Custom Ports on the East Coast & 1997 TEUs & 2008 TEUs & $\begin{array}{r}\text { 12-Year } \\
\text { Growth }\end{array}$ \\
\hline 3 & New York, NY & $1,738,613$ & $3,955,689$ & $127.5 \%$ \\
4 & Savannah, GA & 530,261 & $2,106,437$ & $297.2 \%$ \\
5 & Norfolk, VA & 770,790 & $1,584,632$ & $105.6 \%$ \\
8 & Charleston, SC & 955,620 & $1,325,628$ & $38.7 \%$ \\
11 & Port Everglades, FL & 454,504 & 680,841 & $49.8 \%$ \\
12 & Miami, FL & 623,492 & 669,493 & $7.4 \%$ \\
13 & Baltimore, MD & 260,553 & 430,331 & $65.2 \%$ \\
16 & Philadelphia, PA & 90,517 & 218,055 & $140.9 \%$ \\
18 & Wilmington, DE & 104,200 & 186,918 & $79.4 \%$ \\
20 & Jacksonville, FL & 199,438 & 158,452 & $-20.6 \%$ \\
\hline & Total TEUs All Container Traffic & $14,860,367$ & $28,308,784$ & $90.5 \%$ \\
& Total TEUs Top 20 Container Ports & $14,208,159$ & $27,254,527$ & $91.8 \%$ \\
& Top 20 Share of Total Traffic & $95.6 \%$ & $96.3 \%$ & \\
\hline & Total Top 20 EC Container Ports & $5,727,987$ & $11,316,478$ & $97.6 \%$ \\
& East Coast Share of Top 20 & $40.3 \%$ & $41.5 \%$ & \\
\hline
\end{tabular}

Source: Maritime Administration (2009a).

Approximately $75 \%$ of the U.S. population resides in the eastern part of the United States, and its needs have been filled with a three-coast supply chain strategy: land bridge from the U.S. (and Canadian) West Coast, Panama to Gulf and Southeast Coast ports, and transatlantic (including Suez) from Europe (and Asia). The advent of cross-docking and transload operations for containers have altered the trade flows, and thus the importance and development of land-side networks. Corridor development has been a dynamic process as the private sector railroads have competed fiercely with long-haul trucking to grow business and the largest global corporations engage in streamlining their global supply chain networks. The mature and stable transatlantic route has steadily grown throughout the period.

\section{HINTERLAND CONGESTION AND ACCESSIBILITY}

\section{In North-America}

This has been a critical issue for U.S. East Coast ports like New York New Jersey and Virginia ports but has been less of an issue for the Canadian ports of Halifax and Montreal, where inland connections have been well-developed from the very beginning and on-dock rail access was designed into the initial construction of the container terminals in the 1960s. Port access, however, has been such a problem for many U.S. ports that a major study of landside access was completed in the early 1990s (Transportation Research Board 1993). Examining the nature of the port access problems faced by U.S. ports (including appropriate strategies for dealing with it), the report identified four main areas to be addressed-physical impediments, land use policies, regulatory constraints, and institutional issues. In the intervening years, U.S. ports have looked to their local state and local governments for assistance in dealing with growing congestion in the immediate vicinity of ports and on the corridors connecting ports to the major hinterlands, in part because port policy in the 
United Statesis decentralized (this will be discussed later) and in part because there is a history of local financial support for port activities.

Hinterland congestion has been a factor on the East Coast as truck has competed with car for scarce road capacity in the I-95 corridor. Distribution centers in the mid-Atlantic states (Figure 3) have been developed by major cargo interests to support efficient global networks as the volume of traffic has grown.

More recently, investments intended to streamline access have occurred in the Port of New York New Jersey and in the Heartland Corridor in an effort to address hinterland congestion issues. The Heartland Corridor rail line expansion (completion due in 2010) is the most visionary of the East Coast projects, and investments of US\$309 million will improve the rail corridor from Virginia to Ohio in support the Port of Norfolk's hinterland development to the U.S. Midwest (Federal Highway Administration 2007).

In Canada, the Canadian government introduced a Gateways and Corridors Strategy in 2006 to fund infrastructure improvements, recognizing the critical nature of this infrastructure deficit. While the funding strategy began with investments on the West Coast, each region of the country was allocated a share of funds in the 2007 budget, which committed C\$2.1 billion to gateways and corridors and provided a national gateway and trade corridor policy framework to guide the investment decisions (Government of Canada 2006). The exact allocation of these funds in support of the Atlantic Gateway but has not yet been determined.

\section{Figure 3: Distribution Center Development in the I-95 Corridor}

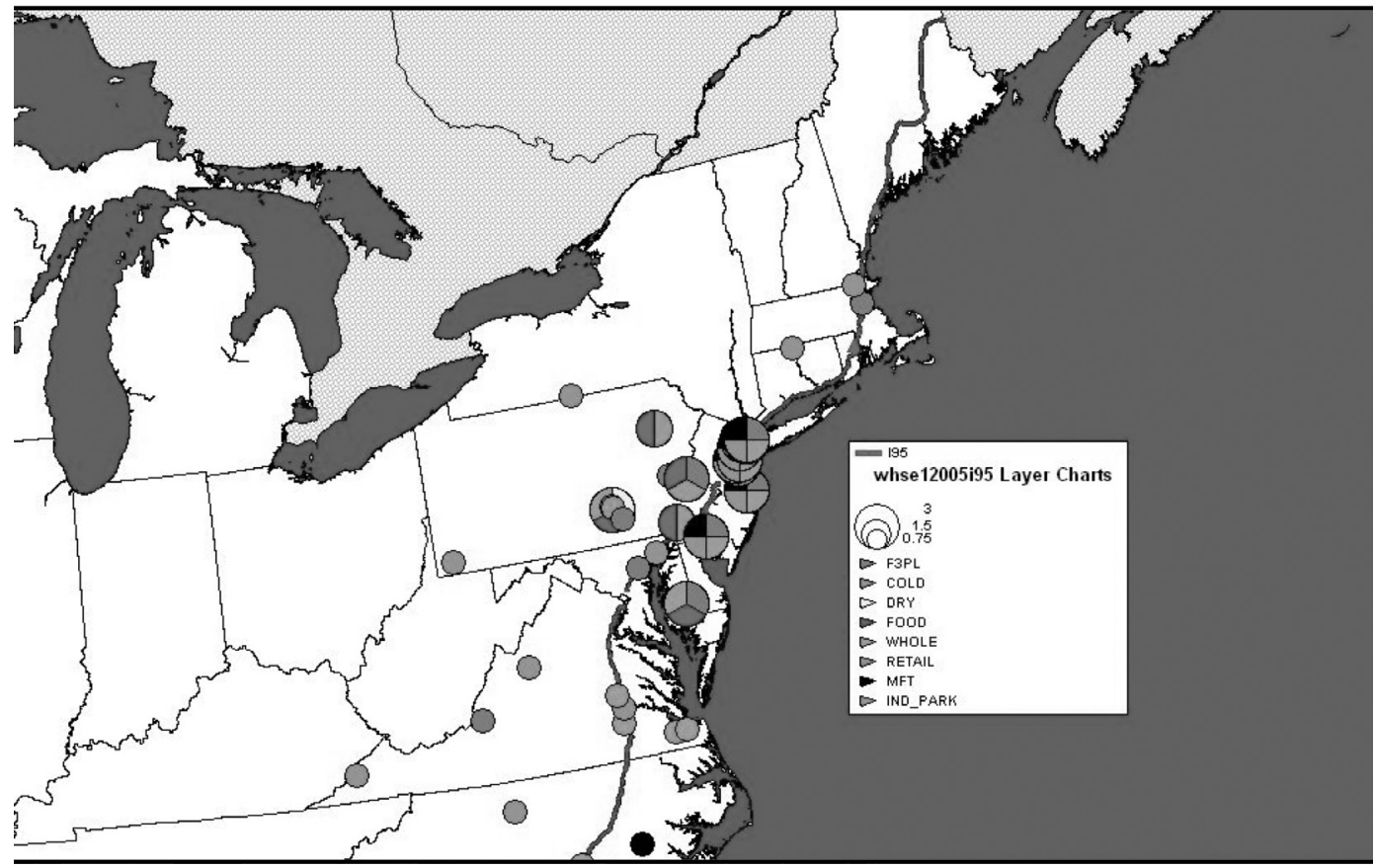

Source: Brooks, Hodgson and Frost (2006), Figure 2.4 p. 14.

Canada and the United States have not been alone in their efforts to address hinterland congestion arising from the burgeoning growth in container trade and the growing population that competes for the use of trade corridors. A recent study by the Joint Transport Research Centre (2008) examined the issue across Europe and North America, as part of a larger study, concluding it to be one of the most significant issues facing ports today and one that lacks consensus on the appropriate role for ports in addressing the challenge. 


\section{Congestion Issues in Europe}

In Europe, hinterland congestion is a huge problem for almost all large load center ports and also for some of the regional ports located adjacent to large cities or within larger, densely populated areas. One of the factors behind this is that the evolution of both ports and cities in Europe has a very long history, but that an integrated approach on this only has emerged over the last few decades. Cities have expanded, putting much more pressure on space and infrastructure, and, on the other hand, ports have expanded, resulting in much more traffic to and from the port.

In a response to increased focus on hinterland accessibility and increasing port and hinterland congestion, we see new logistics concepts arising in Europe. Port and terminal operators, also large container carriers, develop terminal networks in the hinterland through which they transport their cargoes to final destinations. ECT in Rotterdam is developing an extended gate concept, with terminals in Venlo and Amsterdam (Netherlands), Duisburg (Germany), and Willebroek (Belgium) that serve as the gate of the deep-sea terminal. ECT, therefore, controls the transshipment including the inland transport up to the inland terminal. Rotterdam is also developing container transit points, purely for the purpose of avoiding congestion on the port's internal and access roads. Containers will be transported by barge from the deep-sea terminal to the transit point and from there by road or barge. The transit points will be developed in joint effort with port service providers and port users and aimed at cargo for the region.

Since January 2009, Eurogate in Hamburg also offers their customers transshipment service; they are developing an inland terminal network, comprised of a substantial number of mainly rail but also barge terminals, at which they offer a complete spectrum of container services, including warehousing of full containers, empty depot storage, container repair and maintenance, and sale and hire of containers.

As an issue, hinterland accessibility and congestion have reached top policy levels in Europe, and even the wider base of the Organisation for Economic Cooperation and Development and the UN Economic Commission for Europe. Whereas, in the beginning, the focus was rather on the hardware side, current interest in the issue has moved past infrastructure towards information systems, and institutional and organizational changes to enhance hinterland accessibility of ports. This is a common contextual factor that ports, not just in Northwest Europe and the U.S. East Coast, now face.

\section{PORT SECURITY}

\section{North American Perspective}

Prior to the terrorist attacks of 2001, the security efforts of port authorities in North America were mainly targeted towards preventing criminal activities like theft within the jurisdiction of the port. After the attacks, U.S. port authorities and their Canadian counterparts refocused their safety and security agendas towards prevention of incidents and emergency response.

In 2002, the United States passed the Maritime Transportation Security Act of 2002 (MTSA), with effect on July 1, 2004, the same day chosen by the International Maritime Organisation to effect the International Ship and Port Facility Security Code or ISPS Code. However, as many ports operate as landlords, leasing terminals and facilities to private companies, the MTSA limits the security oversight that U.S. port authorities may impose on their tenants. Security compliance, therefore, is primarily a matter between the U.S. government and the private terminal operating companies that lease port premises.

The United States has developed a significant security regime that has had extra-territorial impact. For example, the MTSA instituted rules, such as 96- and 24-hour rules, to reduce the vulnerability of the American container supply chain (GAO 2005). The 96-hour rule requires that all vessels that will call at U.S. ports provide the U.S. government with advance notice of arrival 
96 hours before that arrival is expected, thereby allowing the U.S. government to assess the threat posed by the vessel. The 24-hour rule requires that non-vessel operating common carriers and liner shipping companies provide the U.S. government with 24-hour notice of a container being loaded onto a vessel in a foreign port, thereby allowing the U.S. government to assess the threat posed by the container, its contents, or the individuals who packed it. Both of these rules maximize the advantages of the Automated Targeting System used by U.S. Customs and Border Protection, a part of the Department of Homeland Security. The third plank in the prevention platform is the Transport Workers Identity Credential (TWIC) as required by the Security and Accountability For Every (SAFE) Port Act of 2006. Now more than one million workers have been credentialed.

These security requirements have been mirrored in Canada where possible so that goods traveling to the United States through Canadian ports are not disadvantaged. The Government of Canada has placed a high priority on ensuring that port competitiveness is maintained; in December 2001, the first U.S. customs officers were placed in the ports of Halifax, Montreal, and Vancouver as part of this effort. Security is an area where the United States has led in concept if not always in execution.

\section{European Perspective}

Following the security initiatives undertaken by the United States, the European Union fully agreed with the content of the ISPS code and transposed the associated rules into Community Law, with effect July 1, 2004 (Council Regulation (EC) No. 725/2004). Key to Regulation 725/2004 is that all operational ships and port facilities should have international security certificates issued by the Government as a proof of sufficient compliance with the ISPS Code (Dekker and Stevens 2007). In practice, this means that port facilities and shipping companies have to implement technical as well as organizational measures, such as access and entrance protocols, with their supporting electronic systems, container scan facilities, and additional specialized security personnel. Ports have to identify restricted areas and monitor them carefully to prevent unauthorized access, and implement measures to prevent weapons, dangerous substances, and devices being taken onto ships or into port facilities. Dekker and Stevens (2007) show that, by the beginning of 2004, already $22 \%$ of European ports fully complied with the ISPS Code and that the average compliance of all European ports was about $70 \%$. Thus, only a relatively small effort was needed to fully implement the ISPS code-based Regulation 725/2004, as of July 1, 2004. More important, Regulation 725/2004 extends Code provisions to intra-European and domestic maritime trades.

The two major U.S. maritime cargo security initiatives, the Container Security Initiative (CSI) and the 24-hour Advance Notification Rule (24-hour rule), also have had their impacts on European port strategies, the latter being implemented as a compulsory rule. In the CSI program, foreign ports are asked to pre-screen the containers that are loaded onto vessels that will call at U.S. ports. In execution, the CSI program is dependent on the support of the European port authority. In 2007, there were 23 European CSI ports (including Rotterdam, Antwerp, and Hamburg in Northwest Europe) and the United States and Europe agreed to jointly work on the establishment of fast customs clearance processes at both sides of the maritime leg, meeting joint security requirements.

Following Council Regulation 725/2004 that focused on ships and port facilities, the European Commission developed a policy framework that minimizes security risks throughout the entire transport chain. A first step in this direction has been the endorsement of a revised Community Customs Code, which was set to be fully in force in 2009. Regulation 648/2005, which is similar to the U.S. C-TPAT program and the 24-hour rule, sets up a common EU secure custom system based on the electronic exchange of advance information between traders and customs authorities on all goods entering or leaving the European Union. Within this regulation, the possibility for transport operators to obtain a so-called Authorized Economic Operator (AEO) status is introduced. The criteria for obtaining this AEO status are: 1) compliance record with custom requirements, 
2) satisfactory system of managing commercial records, 3) financial solvency, and 4) appropriate safety and security standards.

Since September 2001, Europe has mainly followed the U.S. security lead and complied with its intents by developing similar regulations, some divergence has occurred lately. The SAFE Port Act, endorsed in 2007 to be fully implemented in 2012, has led to some negative reactions by non-U.S. port stakeholders. Apart from the reciprocity issue, the SAFE Port Act requires every foreign port with U.S.-bound containers to do $100 \%$ container scanning with the appropriate scanning systems. The main criticisms are: a) the unavoidable separation of U.S.-destined containers requires more space, personnel, and operations; b) it is not a risk management approach; 3) it is not clear who will pay for the costs; and 4) it is not clear who will control the commercially sensitive data that are involved with the operations (Pallis and Vaggelas 2007). Ports, responsive to their stakeholders' concerns, have been less enthusiastic about blindly following the U.S. lead.

\section{PORT POLICY, THE ROLE OF THE STATE IN PORT DEVELOPMENT}

\section{European Perspective}

Specific to the European situation is that transport and port policy is not only a national issue but also an issue that is increasingly dealt with at a pan-European level. Over the last two decades, there has been a shift in the European Commission's role from advisor to interventionist in port policy development.

European Transport Policy. European transport policy started with reforms intended to phase in liberalization of the transport market in order to complete its internal market. ${ }^{2}$ In the 2001 transport White Paper (Commission of The European Communities 2001a), the Commission's focus shifted from opening up the transport sector to making the transport system sustainable by decoupling economic growth from transport growth, and by working towards a more integrated European transport network. The primary mechanism for creating an integrated multimodal European transport network is the TEN-T project, which consists of a multitude of discrete projects to build an EU-wide transport network. In 2006, a mid-term review of the progress of the transport policy's implementation took place (Commission of the European Communities 2006). The main conclusions were that, in the first place, the policy recommendations of the 2001 White Paper were still valid, but that a broader more flexible approach is needed. The strict starting point of decoupling economic growth from transport growth was slightly relaxed, and the focus on modal shift has been replaced by a policy aimed at strengthening all modes and integrated transport systems; "comodality" has become the new language. The midterm review furthermore concluded that a new European port policy was needed, further striving for a "level playing field" for ports and providing for the possibility of investments in ports that strengthen the ports and further integrate them into the European transport corridors and network.

The notion that continental maritime transport or short sea shipping can play a role in shifting cargo from road to more sustainable transport modes has resulted in the development of the "Motorways of the Sea" program. This has put the European ports more clearly on the agenda of the European Transport Policy. One of the concrete objectives, as mentioned in Commission of the European Communities (2007), is the integration of the European seaports into the TEN-T program.

Ports are now recognized as key components of freight logistics networks. The key obstacle to the integration of ports into the freight logistics networks is inadequate inland connections, in particular for rail. The 2009 Green Paper underlines that the future TEN-T infrastructure development policy should give particular attention to the appropriate development of a port's infrastructure and more efficient hinterland connections and to the removal of bottlenecks on major transport corridors (Commission of the European Communities 2009). 
European Port Policy. Current European port policy traces back to the 1997 Green Paper (Commission of the European Communities 1997), the first significant policy document for European ports. It initiated a substantial discussion of a key element in European port policyintegration of the European ports in the European transport networks, market access to ports, and financing of and charging for port assets and services. Before 1997, attempts had been made by the European Commission to analyze these issues, but substantial progress had not been forthcoming.

Based on the Green Paper and subsequent discussions, a first port package on market access to port services was proposed in 2001 (Commission of the European Communities 2001b). It resulted in a Europe-wide strike among port workers and was finally rejected by the European parliament. In October 2004, the Commission launched a second proposal that again addressed market access as well as the issue of inter-port competition (Commission of the European Communities 2004). Transparency and state aid guidelines for the financing of port-related investments were expected to result in a level playing field for port services. Although there is common understanding that more transparency in port financing is needed, and that state aid to ports should be restricted, it has been very difficult to translate this into agreed regulation and guidelines. Studies into the financing structures of ports with the aim of identifying state aid that harms the level playing field of ports document that there exists a huge diversity in financing and charging systems of European seaports (Institute of Shipping Economics and Logistics 2006).

In Europe, port reforms started with a gradual increase in the role of the private sector in port services, with ownership and control of the assets remaining with the public sector. The public sector continued to subsidize port-related investments, resulting in a diverse system of public subsidies for port-related investments. Moreover, institutionally European ports differ enormously; even within countries, ports in close proximity can have different governance and ownership structures with port authorities. Therefore, a one-size-fits-all model cannot and will not work. Therefore, it was not surprising that the second port package was also rejected by the European Parliament and withdrawn by the Commission in 2006. The lesson learned was that a more flexible approach to port governance is needed, based on adequate consultation of all stakeholders involved. In October 2007, the European Commission presented its latest communication on ports policy, announcing a number of measures and soft law instruments but with few legislative changes proposed. The principles of the communication are 1) hinterland connections are a highly determining factor in port performance and deserve more attention; 2) expanding capacity is needed but should be done while respecting the environment mostly; 3) ports need a level playing field with clarity for investors, operators and users; 4) to integrate ports well in its civil environment structural dialogues are needed between ports and their adjacent cities; 5) work in ports should comply with societal needs in terms of labor safety and health (Commission of the European Communities 2007).

The real change in the European port policy has been the recent greater involvement of stakeholders in the dialogue, resulting in an understanding that hard legislation will not work due to the diversity in governance and financing and charging systems in ports, and that a soft law approach will better match the specific situation of ports. Common understanding is that a successful ports policy supports competition both within and between ports. This comprises clear rules for public contributions to port related investments, transparent access to port services and creating development potential for competitive services based on high quality labor. Furthermore, the ports policy should, on a structural basis, safeguard the balance between development needs and environmental constraints.

An interesting and yet not answered question is to what extent EU port policy really can influence processes in the Member States and whether it enhances the harmonization of port governance structures throughout Europe (Verhoeven 2009). 


\section{North American Perspective}

Unlike Europe, there is no effort to have a supranational or continental port policy in North America. Canada and the United States have very divergent approaches to transport policy, and port policy in particular. The closest alignment in policy exists for rail and air modes, but even here coordination of policies is very limited. Nowhere is the divergence in thinking more evident than in the policies that govern maritime transport and ports.

Maritime Transport Policy. U.S. shipping policy is premised on the concept that shipping is a national strategic priority and that the defense of the United States is paramount. Ships carrying goods between two ports in the United States operate within a closed market; the goods must use a ship flagged in the United States, owned by U.S. citizens, crewed by U.S. nationals, and built in a U.S. shipyard. On the other hand, Canadian coasting trade (e.g., cabotage) rules require that the ship carrying domestic cargo must be crewed by Canadians and registered in Canada, or be a dutypaid foreign flag vessel operated under a waiver granted by the Canadian Transportation Agency. Vessels operating under waiver carry only about $4 \%$ of Canadian domestic traffic (Brooks 2009). For international traffic, however, both countries have open markets, although international containers, once landed in a U.S. port, are deemed to be domestic containers for purposes of considering the application of cabotage rules.

Port Policy. Again, port policy differs widely between the two countries. Ports in Canada are federally regulated and port policy for the largest ports - those seen to be of national economic importance (known as Canada Port Authorities or CPAs) - is prescribed in the Canada Marine Act. CPAs are required to be financially self-sufficient and are commercialized, non-recourse government agencies. This port policy was reviewed in 2004, and some changes were subsequently made to the regulations governing port access to financing for capital projects (Brooks 2007). On the other hand, there is no national port policy in the United States (Fawcett 2007). Ports are predominantly publicly owned, managed locally or regionally, are highly competitive, and subject to considerable local political influence.

State Aid. As already noted, Canadian ports must be financially self-sufficient; however, they are now able to access Gateway and Corridor funds (previously discussed) if they can present a business case as to why these investments will support Canada's international trade objectives. In the United States, there are limited national resources available for addressing port infrastructure investments, except for that available under such programs as the American Recovery and Reinvestment Act of 2009 (the economic stimulus package) or because inland connections can be improved through the use of funds from the Highway Trust Fund (raised by a gasoline tax). State aid is just thatsupporting funds made available by the state or municipality in which the port resides. State aid for U.S. ports, therefore, may take the form of direct local government support, cross-subsidies from other local revenue-generating infrastructure (e.g., toll bridges, tunnels, or airports) or indirectly via federal subsidies for harbor dredging or federal subsidies in the form of tax-exempt bonds. Port state aid has long been a contentious point for Canadian ports that the playing field for inter-port competition is not level.

\section{DIFFERENCES IN PORT GOVERNANCE}

\section{European Perspective}

Port Governance. Over the last two decades, port governance has changed tremendously in Europe. Not only has the division of ownership and functions between public and private changed but also the legal and institutional position of the port authority organizations, leading to new and different 
management forms. Although the common objective of the reform programs has been to introduce more private sector involvement in ports in order to diminish the lack of financial transparency and involvement of national governments, and to give port authorities more autonomy, the resulting processes and outcomes have been very different.

During the 1990s, port reform in the United Kingdom often involved outright sale, even of regulatory functions (Baird 2000). This resulted in a number of private ports, whereby a private company has become both owner and operator of the port. On the European continent, port reform programs have resulted in so-called landlord ports, whereby a public or semi-public body is responsible for the development and management of the port area and nautical access, and private companies are responsible for port operations and services. Although we can say that, on the continent, port management is still dominated by public entities (Verhoeven 2009), the form in which this happens differs significantly by country. In the northern countries (Baltic, Germany, Benelux), we see municipal port authorities, which in some cases have been corporatized (Rotterdam, Bremerhaven, Gothenburg). In the more southern countries like France, port authorities remain tied to the national government. Although a lot of changes have been made, the reform process in many countries is still not complete.

The changing institutional and market environment has impacted the responsibilities and activities of port authorities (PAs). Competitive factors, such as port facilities, adequate draft and available land, are not sufficient for satisfying the requirements of port users. Additional competitive factors, such as a high-quality labor market, good hinterland access, and information and communications infrastructure, are in the collective interest of all firms in the port cluster, but are generally not provided without an active role for the PA (De Langen and Van der Lugt 2007). Thus, PAs are increasingly under pressure to invest in such competitive factors. This requires an institutional structure that ensures they can do so. For Rotterdam, this has resulted in corporatization of the port authority. The Port of Rotterdam acts as a corporate entity, but its shares are held by both municipal and national governments. This gives the Port of Rotterdam the freedom to develop new capabilities and acquire the financial means needed for making investments and developing new activities. In Amsterdam, discussions are also ongoing about whether or not to corporatize. Whether such governance reform will result in the desired outcomes remains to be seen.

\section{North American Perspective}

The framework of port governance in the United States is complex and very fragmented with a web of public and private organizations involved in management at national, regional, and local levels, each with differing priorities, requirements, and procedures (Newman and Walder 2003; Fawcett 2007). The multitude of jurisdictional forms has led to intense competition among ports and within ports in the United States. Furthermore, U.S. ports are heavily dependent on government (loans, grants and taxes) and tax-exempt revenue bonds for their revenue, and have been argued to be highly inefficient (Helling and Poister 2000). Unlike many other countries, there has not been a reform of port policy in the United States.

In Canada, on the other hand, there was significant and substantial reform of the port system in the 1990s, and the plan for reform was laid out in the National Marine Policy (Transport Canada 1995). The Government of Canada established three models of governance for ports in the country (Brooks 2007). The most important ports (19 in total), in terms of being vital to Canada's international trading role, were deemed to be Canadian Port Authorities, and mandated to be financially selfsufficient in their activities. Remote ports (27 as of May 31, 2009), where the federal government believed it had a public service obligation, were retained as federally owned and controlled. All other ports were de-proclaimed (seen as surplus to national needs) or divested to local or regional interests or to other departments or governments (such as the Department of Fisheries where the primary purpose was to serve the fishery not commercial trading interests) (Transport Canada 2009). 


\section{PORT STRATEGIES AND MANAGEMENT}

\section{European Perspective}

In Europe, the changing market environments not only impacted the institutional structures of ports and port authorities but it has also led to reconsideration by port authorities of their role and strategies. A first strategic question many port authorities in northwest Europe have to deal with is: how do we manage new port expansions? Up to 2008, many of the leading ports in Northwest Europe faced scarcity in capacity. Development plans for up to 30 million TEU in capacity expansion existed in the Le Havre-Hamburg port range, but implementation horizons are very long and even enlarged by discussions on the societal impact of the expansion plans. Getting these plans through the approval process is a matter of smart port authority negotiation with national governments, strong stakeholder interactions, continuous support for the "license to operate" and, in many cases, implementing concrete environmental plans in combination with the physical expansion plans. One example is the Maasvlakte 2 project in Rotterdam; it was only approved to start building after dedicating a substantial part of the reclamation for "nature" and taking specific environment protection measures. The whole decision making process around Maasvlakte 2 was done with intensive involvement of all kinds of stakeholders. Port authorities are also developing specific concession strategies to better manage and control their port land area. They are considering putting in performance requirements and also sustainability requirements.

Another strategic issue port authorities are facing is how to ensure hinterland accessibility (De Langen 2008). As mentioned earlier, hinterland access has become a major issue in port performance and thus of interest to the port authority. In ensuring hinterland accessibility, port authorities are limited in what they can do as operations are done by private companies. Some consider investing in inland terminals (e.g., Port of Barcelona) and hinterland connections (see the previous discussion on Rotterdam), while others establish port community systems to support seamless supply chains or to set access rules on the ports' infrastructure. We conclude that Northwest European ports are very focused on developing hinterland strategies, carefully looking at the position they can take to enhance the performance of the ports' hinterland network.

In their strategy development, Northwest European port authorities increasingly consider whether to act on their own or to develop cooperation with other ports in proximity. Among various Northwest European ports, there are different cooperation initiatives. For example, cooperation was initiated on port expansion between the Port of Rotterdam and Zeeland seaports. Rotterdam and Amsterdam jointly developed a port community system called PortBase. Twice a year the management of the ports of Hamburg, Amsterdam, Rotterdam, Antwerp and Le Havre meet to discuss ongoing issues of mutual concern. The most far-reaching cooperative initiative has been between Copenhagen (Denmark) and Malmo (Sweden) that eventually resulted in a full merger between the two ports. The changed commercial and institutional environment certainly had its influence on these developments: port authorities are facing ever larger customers limiting their own power, and, from the societal side, more and more pressure is put on the performance of ports in terms of sustainability. On the other hand, institutionally, port authorities increasingly have more possibilities to widen their scope of operations.

\section{FINANCING AND CHARGING REGIMES}

There is considerable variety in financing and charging regimes in Europe, often related to the governance model that is in place. A study from ESPO into the various port financing and charging regimes in Europe (ESPO 2004) already illustrated this wide variety. At the moment this still holds. Although there have been many attempts at the European level to avoid state aids to ports and to achieve a level playing field in this issue, financial flows from the various governments to ports still 
occur and there are substantial differences in the financing systems by each country. Some ports are completely self-sustaining, including their sea channels and passage ways; examples are ports in Ireland and the Baltic. Some ports have a division between inside and outside the legally-defined port area, where the state is responsible for the investments in port-related infrastructure outside the port area, and the port authority has this responsibility inside the port perimeter. Examples can be found in Germany, Belgium, and the Netherlands. In some ports there is more structural financial support from the state into ports (e.g., France, Italy).

Following the landlord model, concessions are often awarded by port authorities with considerable variety in concession terms (Notteboom and Verhoeven 2009). There are a wide variety of factors contributing to the structure of concession agreements in Europe, and North America is no different.

Also charging regimes for port services differ widely. Port dues in European ports, in general, are tariff-based, with some involvement of the local or national government. However, depending on the port, there may be room for customer-negotiated rates. In some ports, the government sets charges while, in others, the port authority management controls the charges.

In North America, the situation is similar. The commercialization of Canadian ports through the Canada Marine Act, 1998, gave ports the responsibility to set their own charging regimes and the obligation to live with the financial impact. While many ports initially kept the structure and complexity of port tariffs, there is now a move to make these more commercially-oriented, both in "look and feel" and with favorable line reductions for business activities the port desires to promote, such as feeder traffic or traffic of a particular type. Market-driven tariffs are gradually becoming the norm.

In the United States, the public ownership of ports puts charging mechanisms in local hands. There is no national governance mechanism for ports and no standard approach to port charging. Like Europe, in some ports, government sets charges while, in others, the port authority management controls the charges. Some ports are more market-oriented and others less so.

In summary, there is no standard model for either financing or charging but, as with the worldwide trend towards concessions, it is always location-specific and dependent on the governance regime in place.

\section{CONCLUSIONS}

Although the northern transatlantic trade does not dominate the global maritime trade network, it is a substantial trade for both North American and Northwest European ports and shows a relatively low but stable share of global traffic. The port systems on both sides of the Atlantic differ mainly in terms of the number of ports that service each geographic region and how they are governed. They also differ in terms of port management strategies for dealing with the key environment (context) issues they face and the structures imposed by governance regulation, to use the eEnvironmentStructure-Strategy approach by Baltazar and Brooks (2007).

First, the U.S. and Canadian east coasts have a relatively small number of ports in comparison with Europe, where ports are larger and closer together. While this implies that the contestability of their hinterlands is more critical in the European context than in the North American context, this is not necessarily true. Both sets of ports compete as parts of supply chains and these may be continental or intercontinental in both cases. In the environment faced by ports, hinterland boundaries are set by economics rather than by politics and regulation, but the future success of port authority strategies may be dampened by lack of progress on harmonizing port governance in Europe (structure) and by border irritants in the case of North America (environment).

Second, there is the issue of how ports respond to the environment issue of security. Ports in North America and Europe began by adopting the U.S. and IMO security standards. However, as U.S. requirements continue to grow ever more stringent, the SAFEPort Act's requirement for 100\% scanning has, for many European ports, become an unacceptable addition to the security regime. 
Whether this strategy of acceptance will become one of resistance is unclear, but there is some pushback already in evidence.

In Europe, the ports have found that their environment is best managed through the development of a strategy that goes beyond the provision of a safe and sustainable port area and nautical access. The growing importance of uncongested and efficient hinterland accessibility has resulted in the development of coordination and cooperation strategies within the hinterland networks and between ports in proximity.

In the North American case, the reach of the freight railroads has meant most container ports have and serve a continental hinterland, and compete fiercely for it. There is little strategic cooperation among ports, as the issue of being in proximity is less the case in North America. Also, they are much less likely to be active participants or leaders in coordination strategies as their governance, in the case of Canada, limits their strategic product scope; in the case of the United States, their local political masters have not demonstrated an interest in expanding public service obligations.

Finally, the finance and charging strategies are location, and hence context-specific and structure-specific.

In conclusion, the two main issues that are increasingly relevant in the external context (environment) affecting the structure/strategy relationship of the transatlantic ports are port congestion in relation to hinterland accessibility and port security. Port congestion appears to be a bigger issue in Northwest Europe than in North America, perhaps as a function of the population density. Neither region has a streamlined approach to port governance, and this could well limit the development of appropriate strategies by port authorities, particularly in the North American context.

\section{Endnotes}

1. While geographically North America is considered to include Mexico, and this was further supported by the negotiation of the North American Free Trade Agreement, the transatlantic trade has always been defined to not include Gulf of Mexico or Caribbean traffic, and so Mexico is by usage excluded. Unless specifically included, assume it is excluded from this paper.

2. Sea transport was mentioned in the Treaty of Rome in the late 1950s, but was not part of Europe's Common Transport Policy, mainly because EC's focus was more on continental transport.

\section{References}

Baird, Alfred J. "Port Privatisation: Objectives, Extent, Process and the U.K. Experience." International Journal of Maritime Economics 2 (3), (2000): 177-194.

Baltazar, R. and M. R. Brooks. "Port Governance, Devolution and the Matching Framework: A Configuration Theory Approach." Mary R. Brooks and Kevin Cullinane eds. Devolution, Port Performance and Port Governance, Research in Transport Economics 17, (2007): 379-404.

Brooks, M. R., R. McCalla, A. A. Pallis, and L. Vanderlugt. "Coordination and Cooperation in Strategic Port Management: The Case of Atlantic Canada's Ports." Presentation to the 2009 Annual Meeting of the International Association of Maritime Economists, Copenhagen, June 2009.

Brooks, M. R. and K. Cullinane. "Introduction." Mary R. Brooks and Kevin Cullinane eds. Devolution, Port Performance and Port Governance, Research in Transport Economics 17, (2007): 3-28. 
Brooks, M. R. "Port Devolution and Governance in Canada." Mary R. Brooks and Kevin Cullinane eds. Devolution, Port Performance and Port Governance, Research in Transport Economics 17, (2007): 237-258.

Brooks, Mary R., J.R.F. Hodgson and J. D. Frost. Short Sea Shipping on the East Coast of North America: An Analysis of Opportunities and Issues. Halifax: Dalhousie University. Project ACGTPMI-AH08, Transport Canada, 2006. Http://management.dal.ca/Research/ShortSea.php

Brooks, Mary R. "Liberalization in Maritime Transport," Paper for the International Transport Forum 2009 on Transport for a Global Economy: Challenges and Opportunities in a Downturn. Joint Transport Research Centre of the Organisation for Economic Cooperation and Development, Leipzig, May 26-29, 2009. Http://www.internationaltransportforum.org/2009/workshops/pdf/ws1Brooks.pdf

Commission of the European Communities. "Communication on a European Ports Policy." COM616 final, 2007.

Commission of The European Communities. "Green Paper - TEN-T: A Policy Review - Towards a Better Integrated Trans-European Transport Network at the Service of the Common Transport Policy." Com 44, February 2009.

Commission of the European Communities. "Proposal for a Directive of the European Parliament and of the Council on Market Access to Port Services." COM 654 final, 2004.

Commission of the European Communities. Reinforcing Quality Service in Sea Ports: A Key for European Transport. COM 0035 final, 2001b.

Commission of the European Communities. "Communication from the Commission to the Council and the European Parliament. Keep Europe Moving -Sustainable Mobility for Our Continent." Mid-term Review of the European Commission's 2001 Transport White Paper [COM(2006)314]. Office for Official Publications of the European Communities, Luxembourg, 2006.

Commission of the European Communities. "Green Paper on Sea Ports and Maritime Infrastructure." COM (97) 678 final, 1997.

Commission of the European Communities. "White Paper. European Transport Policy for 2010: Time to Decide" [COM(2001)370]. Luxembourg: Office for Official Publications of the European Communities. 2001a.

De Langen, P.W. "Ensuring Hinterland Access: The Role of Port Authorities." OECD/ITF Discussion Paper, No 2008-11. Http://www.internationaltransportforum.org/jtrc/DiscussionPapers/DP200811. $\operatorname{pdf}(2008)$

De Langen, P.W. and L.M. Van der Lugt. "Governance Structure of Ports in The Netherlands." Mary R. Brooks and Kevin Cullinane eds. Devolution, Port Performance and Port Governance, Research in Transport Economics 17, (2007): 207-236.

Dekker, S. and H. Stevens. "Maritime Security in the European Union-Empirical Findings on Financial Implications for Port Facilities." Maritime Policy and Management 34(5), (2007): 485499.

Drewry Shipping Consultants. "Annual Container Market Review and Forecast 2008/09." Http://www.drewry.co.uk/publications/view_publication.php?id=333 (2008). 
ESPO. "Factual Report on the European Port Sector (2004-2005).” 2004. Http://www.espo.be

Eurostat. Comext External Trade Database. 2009. Http://epp.eurostat.ec.europa.eu/newxtweb/ defaultquery.do

Fawcett, James A. "Port Governance and Privatization in the United States: Public Ownership and Private Operation.” Mary R. Brooks and Kevin Cullinane eds. Devolution, Port Performance and Port Governance, Research in Transport Economics 17, (2007): 207-236.

Federal Highway Administration. PPP Case Studies: Heartland Corridor. Http://www.fhwa.dot. gov/PPP/heartland.htm (2007).

Government Accountability Office. Homeland Security: Summary of Challenges Faced in Targeting Oceangoing Cargo Containers for Inspection, GAO-04-557T. Washington, D.C.: Government Accountability Office. 2005.

Government of Canada. Budget 2007: Chapter 5. Ottawa: Government of Canada, October. Http:// www.budget.gc.ca/2007/bp/bpc5be.html (2006).

Helling, A. and T.H. Poister. "U.S. Maritime Ports: Trends, Policy Implications, and Research Needs.” Economic Development Quarterly 14, (2000): 300-317.

Institute of Shipping Economics and Logistics. "Public Financing and Charging Practices of Seaports in the EU." Http://ec.europa.eu/transport/maritime/studies/doc/2006_06_eu_seaports_ study.pdf (2006).

Joint Transport Research Centre of the Organisation for Economic Cooperation and Development and the European Council of Ministers of Transport. "Port Competition and Hinterland Connections: Summary and Conclusions" (Discussion Paper 2008-19). Paris, April 10-11, 2008. Http://www. internationaltransportforum.org/jtrc/DiscussionPapers/DP200819.pdf (2008)

Journal of Commerce. “The JoC's Top 50 World Container Ports.” 31 July (2008): 28-36.

Levinson, M. The Box: How The Shipping Container Made The World Smaller and The World Economy Bigger. Princeton University Press, Princeton, NJ, 2006.

Maritime Administration. “U.S. Vessel Calls by Type of Vessel.” Http://www.marad.dot.gov/ports_ landing_page/ports_landing_page.htm (2009b).

Maritime Administration. "U.S. Waterborne Foreign Container Trade by U.S. Custom Ports." Http:// www.marad.dot.gov/ports_landing_page/ports_landing_page.htm, (2009a).

Newman, D. and J.H. Walder. "Federal Ports Policy." Maritime Policy and Management 30 (2), (2003): 151-163.

Notteboom, T. "Economic Analysis of the European Seaport System." Report for the European Sea Ports Organisation, Antwerp: ITMMA, University of Antwerp (2009).

Notteboom, Theo and Patrick Verhoeven. "The Awarding of Seaport Terminals to Private Operators: Current Practices and Viewpoints in European Ports." (Paper 2-68). E-Proceedings of the Annual Meeting of the International Association of Maritime Economists, Copenhagen, June 26 (2009).

Pallis, A.A. and G. K. Vaggelas. "Port and Maritime Security: A Critical Analysis of Contemporary EU Policies." Proceedings of the International Symposium on Maritime Safety, Security and Environmental Protection, Athens, Greece (2007). 
Statistics Canada. "Shipping in Canada, 2006." Ottawa: Statistics Canada. Cat. No.54-205-X. Http://dsp-psd.pwgsc.gc.ca/collection_2009/statcan/54-205-X/54-205-x2006000-eng.pdf (2009).

Transport Canada. "National Marine Policy 1995.” December (1995).

Transport Canada. "Port Programs Transfer Inventory (as of May 31, 2009)." Http://www.tc.gc.ca/ programs/ports/transferinventory.htm, (2009).

Transportation Research Board. "TRB Special Report 238: Landside Access to U.S. Ports." Washington, D.C.: National Academy Press (1993).

U.S. Army Corps of Engineers, "Waterborne Commerce of the United States 2006." Http://www. ndc.iwr.usace.army.mil/wcsc/pdf/wcusat106.pdf (2008).

Verhoeven, P. “European Ports Policy.” Maritime Policy and Management 36 (1), (2009): 79-101.

Watson, David. "The Atlantic Gateway and the Suez Opportunity." Halifax: Speech to the Atlantic Provinces Transportation Forum, 12 October 2007.

Mary R. Brooks is the William A. Black Chair of Commerce at Dalhousie University, Halifax, Canada. She is the founder and chair of the Port Performance Research Network, a network of more than 50 scholars interested in port governance and port performance issues. Her research interests include transportation and global supply chain management, and she is particularly focused on relationships between the buyers and sellers of transportation services. Dr. Brooks received her undergraduate degree from McGill University, her MBA from Dalhousie University, and her Ph.D. in Maritime Studies from the University of Wales in 1983.

Larissa van der Lugt has 14 years 'research and project management experience in ports, transport and logistics. At the Department of Port Economics at Erasmus she is a senior researcher in the fields of port and maritime economics, port management and port-related logistics development, while working on her Ph.D. Before joining the economics faculty in 2003, she worked as a transport economist in a commercial BV of Erasmus, with the Dutch Ministry of Transport, and with a consulting and engineering company. In all these functions she worked, mainly as project leader, on research projects in port development analyses, logistics chain analyses, economic impact studies, and implementation projects for intermodal transport concepts. 